\title{
Young Shakespeare/Late Shakespeare: The Case of Pericles
}

\author{
Lucy Munro
}

\section{(2) OpenEdition}

\section{Journals}

\section{Electronic version}

URL: http://journals.openedition.org/shakespeare/3668

DOI: 10.4000/shakespeare.3668

ISSN: 2271-6424

\section{Publisher}

Société Française Shakespeare

\section{Electronic reference}

Lucy Munro, "Young Shakespeare/Late Shakespeare: The Case of Pericles », Actes des congrès de la Société française Shakespeare [Online], 34 | 2016, Online since 01 March 2016, connection on 30 April 2019. URL : http://journals.openedition.org/shakespeare/3668 ; DOI : 10.4000/shakespeare.3668

This text was automatically generated on 30 April 2019.

(C) SFS 


\title{
Young Shakespeare/Late Shakespeare: The Case of Pericles
}

\author{
Lucy Munro
}

1 I begin with lines from an epilogue by John Dryden, ${ }^{1}$ first printed in his Miscellany Poems in 1684:

Shakespeare's own Muse her Pericles first bore:

The Prince of Tyre was elder than the Moor.

'Tis miracle to see a first good play,

All hawthorns do not bloom on Christmas Day. ${ }^{2}$

Dryden appears to have considered Pericles a youthful work, Shakespeare's first play. He contrasts its modest achievement with that of Othello, here positioned as a work of the dramatist's maturity, and aligns its perceived deficiencies with its chronological position within the canon of Shakespeare's works. "A slender poet must have time to grow", he comments, "no man can be Falstaff-fat at first" (1. 20, 23). As I explain below, although it was viewed as an early play for much of the eighteenth and early nineteenth centuries, by the late nineteenth century Pericles had been re-dated to around 1608, and had instead become the first of Shakespeare's "late" plays. The play thus provides an intriguing index of changing ideas about the nature of Shakespeare's activities and achievement at each end of his career; it is part of a process during which new ideas about the writing life appeared, and the chronology and limits of the Shakespearean canon were established. Moreover, while the boundaries between what is early and what is late may appear fixed, Pericles's reception at the hands of critics, editors and producers also exhibits a series of seemingly contradictory moments at which binary oppositions between early and late, young and old, are put under strain.

2 This essay examines the responses of critics, editors and theatre-makers to Pericles, tracing the processes through which the play moved from "early" to "late" and exploring the impact on page and stage of the idea that Pericles is a late play. The first section, "Early Pericles/Late Pericles", draws on the work of Nicholas Rowe, Edmond Malone, Hermann Ulrici, F.G. Fleay, Edward Dowden and others, exploring the positioning of Pericles at or near the start of Shakespeare's writing career, the processes through which 
it became a late play, and the ways in which critics have characterised "early" and "late" writing. The second section, "Late Marina", examines recent editorial and theatrical responses to Marina's encounter with Lysimachus in the brothel in Act 4, Scene 5, in the context of widespread acceptance of the play's late date and collaborative authorship. ${ }^{3}$ It explores in detail two theatrical revivals and two editions of the late twentieth and early twenty-first centuries: Terry Hands's 1969 Royal Shakespeare Company production at the Royal Shakespeare Theatre; Gary Taylor's edition of Pericles in The Oxford Shakespeare: The Complete Works (1986); David Thacker's 1989 RSC production at the Swan; and Roger Warren's single-volume edition for the Oxford Shakespeare (2003). All of these versions of Pericles have sought to conflate the text of the play printed in quarto in 1609 as The Late, and Much Admired Play, called Pericles, Prince of Tyre, with another version of the story, George Wilkins's The Painful Adventures of Pericles, Prince of Tyre, published in 1608. I argue that through the interventions of these directors and editors, Pericles has become more securely "late" than at any other point in its history, and thus an inextricable part of the Shakespearean canon despite its status as a co-written play.

\section{Early Pericles/Late Pericles}

3 For Dryden in the 1680s, an early play was characterised by aesthetic deficiencies that should be indulged because of the author's youth; the composition of early, unsatisfactory work, he thought, was inevitable even for giants such as Jonson, Fletcher and Shakespeare. His remarks on Pericles were one of two shaping influences on the eighteenth- and early nineteenth-century reception of the play, alongside Nicholas Rowe's unsupported assertion in his 1709 edition of Shakespeare's works that "there is good Reason to believe that the greatest part of that Play was not written by him; tho' it is own'd, some part of it certainly was, particularly the last Act". ${ }^{4}$ Although he was one of the first to comment on the chronological order of Shakespeare's plays, ${ }^{5}$ Rowe was ambivalent about the very idea of an "early" Shakespeare. It would, he writes, be "without doubt a pleasure to any Man [...] to see and know what was the first Essay of a Fancy like Shakespear's", but he appears reluctant to grant Shakespeare a literary apprenticeship:

Perhaps we are not to look for his Beginnings, like those of other Authors, among their least perfect Writings; Art had so little, and Nature so large a Share in what he did, that, for ought I know, the Performances of his Youth, as they were the most vigorous, and had the most fire and strength of Imagination in 'em, were the best. ${ }^{6}$

In an implicit rebuke to Dryden, who appears to see Pericles as an early play at least in part because it is imperfect, Rowe suggests that a "natural" and untaught genius such as Shakespeare may not have had the career pattern of a normal writer.

Rowe's doubts about the authorship of Pericles were to prove more enduring than his ideas about the start of Shakespeare's writing career, and - along with Dryden's conviction that the play was a juvenile work - they left their mark on most of the earliest attempts to date and put in order all of Shakespeare's plays. ${ }^{7}$ In Edmond Malone's influential chronology, published in 1778 , Pericles appears in the italics used to distinguish plays of doubtful authorship:

1. Titus Andronicus, 1589.

2. LOVE'S LABOUR LOST, 1591.

3. FIRST PART OF KING HENRY VI, 1591.

4. SECOND PART OF KING HENRY VI, 1592. 
5. THIRD PART OF KING HENRY VI, 1592.

6. Pericles, 1592.

7. Locrine, 1593.

8. THE TWO GENTLEMEN OF VERONA, 1593.

9. THE WINTER'S TALE, 1594.

10. A MIDSUMMER NIGHT'S DREAM, $1595 .^{8}$

Malone placed Pericles in the early years of Shakespeare's career, in part because he thought that the use of a chorus and dumbshows was characteristic of drama of the early 1590s, and in part because - as he wrote in 1780 - "[t]he wildness and irregularity of the fable, the artless conduct of the piece, and the inequalities of the poetry, may, I think, be all accounted for, by supposing it either his first or one of his earliest essays in dramatick composition". ${ }^{9}$ Moreover, the fact that the plays now grouped together as the "late" plays were not yet conceived of as a unit is clear: Malone dates Pericles to 1592, The Winter's Tale to 1594 , Henry VIII (treated as a play of single authorship) to 1601, Cymbeline to 1604 and The Tempest to 1612; The Two Noble Kinsmen does not feature. ${ }^{10}$

Pericles does not appear in Edward Capell's "SCHEME of their Succession", a chronology probably drawn up in the 1760s but not published until his Notes and Various Readings to Shakespeare were issued posthumously in $1783 .{ }^{11}$ However, the play is described in suggestive terms in two attempts by Samuel Taylor Coleridge to put the plays in order, the first perhaps drawn up in 1802 and the other in 1819. The earlier list places Pericles at the end of a "First Epoch" consisting mainly of plays added to a second issue of the third folio edition of Shakespeare's Comedies and Tragedies in 1664, such as The London Prodigal, but also including Henry VI and 'The old Taming of the Shrew' (i.e. The Taming of a Shrew). These plays are described as "transition-works, Uebergangswerke; not his, yet of him". ${ }^{12}$ The later list attaches to Pericles an alternative loan-word, taken from Italian rather than German:

I think Shakspeare's earliest dramatic attempt - perhaps even prior in conception to the Venus and Adonis, and planned before he left Stratford - was Love's Labour's Lost. Shortly afterwards I suppose Pericles and certain scenes in Jeronymo [The Spanish Tragedy] to have been produced; and in the same epoch, I place the Winter's Tale and Cymbeline, differing from the Pericles by the entire rifacimento [recasting or adaptation] of it, when Shakespeare's celebrity as poet, and his interest, no less than his influence as manager, enabled him to bring forward the laid by labours of his youth. ${ }^{13}$

Pericles thus moves from being übergangswerk - a term registering Coleridge's apparent belief that these were revisions or collaborative works - to being a rifacimento, a work that Shakespeare himself revised from his own earlier draft.

By the early nineteenth century, Pericles appeared to have reached a relatively secure position on the margins of the Shakespearean canon, characterized as early, immature, childish and, often, as either a revision or a collaboration. But in 1839, John Payne Collier permanently unsettled its status when he produced new evidence that the play had been current on the stage around 1608. First, he demonstrated that Malone had been mistaken in thinking that the poem Pimlyco, or Run Red-Cap (1609), which mentions Pericles as an example of the crowds that swarm "at a new play", had received an earlier edition in 1596. Second, he introduced readers to George Wilkins's The Painful Adventures of Pericles, Prince of Tyre (1608), which he describes as "a prose novel, founded upon Shakespeare's Pericles, in consequence, in all likelihood, of the great run it was experiencing", demonstrating its clear relationship with the version of the play published in quarto in $1609 .{ }^{14}$ 
7 Faced with such evidence, scholars who favoured an early date for Pericles began to argue that the extant text was adapted from an earlier play, written either by Shakespeare himself or another dramatist. ${ }^{15}$ An especially potent example of this belief can be seen in the work of Collier himself, who succumbed to temptation and added the forged words " for Pericles" to an entry for "spangled hoes" (hose) in a clothing list drawn up by Edward Alleyn around 1601-1602. ${ }^{16}$ An important theorist of late Shakespeare, Hermann Ulrici, continued to think that Pericles was "a youthful production, which, however, Shakspeare partially remodelled in 1608," and he offers a useful summary of the characteristics he perceives in Shakespeare's "first period", in which he includes Titus Andronicus, The Two Gentlemen of Verona, The Comedy of Errors, Love's Labour's Lost, The Taming of the Shrew, Henry VI and Pericles:

I consider that such plays [...] still exhibit a certain youthful awkwardness, harshness, and immoderation; at one time an inclination to Marlowe's bombast, at another to Greene's diffuseness and superficiality, a certain ruggedness and abruptness, not only of language, but in the whole way in which the subject is treated. [...] In his comedies [...] puns still predominate too much; the situations are still frequently somewhat unnatural; the characters still appear without any marked individuality, now and then still without solidity, wavering, and uncertain. [...] [T]he young poet has not yet succeeded in gathering the multifarious threads into one centre, and in fusing the different parts internally into one harmonious whole; the composition is still more like a mechanical arrangement than a united organisation..$^{17}$

While his account is more detailed than Malone's, it shares its essential characteristics and concerns: the characteristics of "early" style are imitativeness, formal and linguistic irregularity, roughness and excess, unnaturalness of characterisation and situation, and a general lack of harmony.

Other scholars, in contrast, began to take seriously the idea that Pericles may have been written around 1608, and that it might be a collaboration with Wilkins himself. Alongside these developments, The Winter's Tale and Cymbeline were also increasingly being viewed as products of the final years of Shakespeare's career, and new patterns thus began to emerge. As early as 1847, Gulian C. Verplanck could contend that if one were to place before a reader unfamiliar with Pericles "a prose abstract of the plot, interspersed with large extracts from the finer passages, he would surely wonder why there could have been a moment's hesitation in placing PERICLES by the side of CYMBELINE and the WINTER'S TALE". ${ }^{18}$ These developments are reflected in the work of Edward Dowden, whose ideas have had probably the most lasting influence on conceptions of "late" Shakespeare.$^{19}$ In 1875, Dowden included in Shakspere: A Critical Study of his Mind and Art a "Trial Table of the Order of Shakspere's Plays" devised by F.J. Furnivall. "Pericles, part" is placed as the first work of the "Fourth Period" - alongside The Two Noble Kinsmen, The Tempest, Cymbeline, The Winter's Tale and "Henry VIII., part" - and is discussed within the chapter on "Shakspere's Last Plays". ${ }^{20}$

Yet the place of Pericles within the Shakespearean canon remained uncertain. Dowden clearly felt emboldened to treat it as a "last play" by F.G. Fleay's 1874 essay "On the Play of Pericles". Fleay argued that Acts 3-5, with the exception of the brothel scenes, had been composed and abandoned by Shakespeare, who then reworked aspects of his Pericles in writing The Winter's Tale; he ascribed the rest of the extant play to Wilkins and William Rowley. ${ }^{21}$ Alongside his essay, he prints a version of the eight-scene "Shakespearean" version of Pericles under the title "The Birth and Life of Marina, Daughter of Pericles Prince of Tyre". ${ }^{22}$ Dowden refers to the "lovely little romance which Mr Fleay has separated from 
the coarse work of Rowley and Wilkins", and it is this Marina that he views as the first of the "last" plays. Nonetheless, Pericles remains marginal in his conception of the final years of Shakesepeare's career. For example, when he summarises the main characteristics of the plays of this period, Pericles is relegated to a footnote:

Characteristics of versification and style, and the enlarged place given to scenic spectacle, indicate that these plays were produced much about the same time. But the ties of deepest kinship between them are spiritual. There is a certain romantic element in each. $\dagger$ They receive contributions from every portion of Shakspere's genius, but all are mellowed, refined, made exquisite; they avoid the extremes of broad humor and of tragic intensity; they were written with less of passionate concentration than the plays which immediately precede them, but with more of a spirit of deep or exquisite recreation.

†The same remark applies to Shakspere's part of Pericles, which belongs to this same period. ${ }^{23}$

As Dowden explicitly argues and Verplanck implicitly acknowledges, by the mid-late nineteenth century the grouping of the "last" plays together was not merely a point of chronology but one of style, genre and aesthetic purpose. Only two years later, in 1877, Dowden's thinking had developed further. His popular primer for students, Shakspere, includes a revised version of the chronology grouping Pericles, Cymbeline, The Tempest and The Winter's Tale together under the heading "ROMANCES". ${ }^{24}$ Although he describes Pericles as a "sketch", Dowden also integrates it fully within this group, noting that it is "in some respects like a slighter and earlier Tempest" and also comparing its representation of the lost daughter and her recovery with those of The Winter's Tale and Cymbeline. ${ }^{25}$ Dowden's treatment of Pericles thus suggests some of the violence that was done to Pericles in order to cast it as a late play or romance. While its re-dating to 1608 placed it in close chronological proximity to The Tempest, The Winter's Tale and Cymbeline, it could only be read with them as a "romantic" work, "mellowed, refined, [and] made exquisite" if certain scenes were expelled as non-Shakespearean.

11 Malone's description of Pericles, Ulrici's account of early style and Dowden's description of the romances may seem to have little in common - there appears to be considerable distance between "wildness and irregularity" on one hand, and mellow, "exquisite" refinement on the other. However, the characteristics attributed to early and late writing are more slippery than this might suggest, and the categories often appear prone to collapse into one another. In Shakespeare and the Idea of Late Writing, Gordon McMullan outlines a series of binaries that have structured ideas about late style:

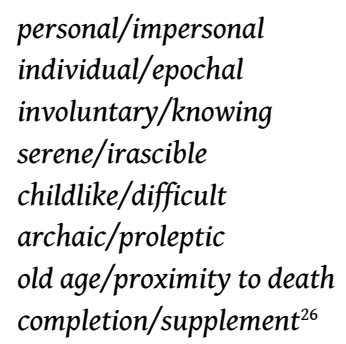

12 These binaries might be set alongside a similar set of simultaneously helpful and confusing categories for early, juvenile or apprentice writing: 


\begin{tabular}{|l|l|}
\hline Late & $\begin{array}{l}\text { Early } \\
\text { original/imitative } \\
\text { personal/impersonal } \\
\text { individual/epochal } \\
\text { involuntary/knowing }\end{array}$ \\
serene/irascible & naive/precocious \\
childlike/difficult & placid/impatient \\
archaic/proleptic & simple/obscure \\
old age/proximity to death & primitive/proleptic \\
completion/supplement & initiation/transition \\
\hline
\end{tabular}

Moreover, we might add two further categories for both early and late writing (I retain McMullan's italics to maintain visually the distinction between the categories):

\begin{tabular}{|c|c|}
\hline $\begin{array}{l}\text { Late } \\
\text { integration/disintegration } \\
\text { individual/collaborative }\end{array}$ & $\begin{array}{l}\text { Early } \\
\text { formal/formless } \\
\text { individual/collaborative }\end{array}$ \\
\hline
\end{tabular}

14 As these lists suggest, the attributes of these stages of a writer's career are liable to collapse into each other, and one work might easily fulfil the requirements of both late and early style. The aesthetic disjunctions and generic uncertainties of Pericles - what Malone viewed as the "irregularity of the fable, the artless conduct of the piece, and the inequalities of the poetry" - might be viewed as the products of both immaturity and age, of primitive incompetence and artfully designed archaism, of a proleptic reaching forward to both artistic maturity and impeding death. This conceptual and practical slippage is not created purely by age itself, or even by the idea that old age is a second childhood; Shakespeare (born 1564) was only in his mid forties when Pericles was written and Wilkins (born around 1576) was even younger. Moreover, although we know that early modern dramatists were likely to collaborate with other writers at all stages of their careers, theoretical models of the writing life are nonetheless likely to attribute it mainly to beginners and veterans.

As they moved into the twentieth century, scholars and editors of Shakespeare thus had a new set of working theories about Pericles. No longer an "early" work, or Shakespeare's first play, for the majority of commentators it had become the first of the "late" plays. The idea that the play was the product of collaboration, probably between Shakespeare and Wilkins, was becoming increasingly accepted, and the quarto's deficiencies began to be attributed to the idea that it was a reported text or a memorial reconstruction. ${ }^{27}$ Yet its position was still in some respects liminal. As the first of the late plays it remained a transition-work, or übergangswerk, as Coleridge termed it. As a collaboration, it was only partially a "late" play, and distaste for the overt sexuality of the incest plot and the brothel scenes continued to limit its exploration by critics. In addition, its performance around 1608 meant that it had been composed before the King's Men took over the Blackfriars playhouse and - unlike the The Tempest, The Winter's Tale and Cymbeline - it could not possibly have been composed with that playhouse in mind. ${ }^{28}$ Moreover, its general absence from the stage meant that it spent the late nineteenth and early twentieth century as part of a print canon but not a performance one..$^{29}$ When Pericles 
finally returned to prominence on the stage from the 1940s onwards, its new presence within the theatrical tradition put new pressures on its status as a late play, and - as I will argue - editorial and theatrical revision became increasingly intertwined.

\section{Late Marina}

The final two acts of Pericles are structured around a series of transformations and revelations: Marina "converts" Lysimachus, who comes to her as a customer in the brothel (Act 4, Scene 5); she encounters the still-grieving Pericles, the circumstances of her birth are revealed, and father and daughter are reunited (Act 5, Scene 1); Pericles and Marina are reunited with the reborn Thaisa (Act 5, Scene 2). While the third and, especially, the second of these moments have been central to readings of Pericles as a "late" play, the first has proved more problematic. The quarto's version of the climax of the exchange between Marina and Lysimachus is brief, poorly printed, and poses various textual problems; in addition, it presents versions of the two characters that have unsettled some readers:

Ma[rina]. If you were borne to honour, shew it now, if put vpon you, make the iudgement good, that thought you worthie of it.

Li[simachus]. How's this? how's this? some more, be sage.

Ma. For me that am a maide, though most vngentle Fortune haue plac't mee in this Stie, where since I came, diseases haue beene solde deerer then phisicke, that the gods would set me free from this vnhalowed place, though they did chaunge mee to the meanest byrd that flyes i'th purer ayre.

Li. I did not thinke thou couldst haue spoke so well, nere dremp't thou could'st, had I brought hither a corrupted minde, thy speeche had altered it, holde, heeres golde for thee, perseuer in that cleare way thou goest and the gods strengthen thee.

$M a$. The good Gods preserue you.

Li. For me be you thoughten, that I came with no ill intent, for to me the very dores and windows sauor vilely, fare thee well, thou art a peece of vertue, \& I doubt not thy training hath bene noble, hold, heeres more golde for thee, a curse vpon him, die he like a theefe that robs thee of thy goodnes, if thou doest heare from me it shalbe for thy good. ${ }^{30}$

17 The punctuation and lineation of the quarto text both appear to be defective, and the majority of editors have made at least minor amendments to the dialogue. For example, in her Arden Shakespeare Third Series edition, Suzanne Gossett amends "For me be you thoughten, that" to "For me, be you bethoughten that" (1. 113); she also adds a direction for Lysimachus to give Marina gold, which is clearly signalled in the text (1.111).

In the version of the scene presented in the quarto, and editions such as Gossett's that are based on it, Lysimachus comes to the brothel - at which he is clearly a long-standing customer - intending to have sex with Marina, but he is quickly, perhaps shockingly quickly, converted by her. There is something sardonic or potentially even savage about the exchange, in which he shiftily attempts to convince Marina that he never intended to pursue a sexual liaison; he repeatedly gives her money, as if embarrassed or ashamed, but the gold itself reminds us of the kinds of sexual transactions that would usually take place in the brothel. In addition, as Gossett notes, his ambiguous response to Marina is emphasised when "he curses the person, his own double, who will attempt to rob 'thee of thy goodness"'. ${ }^{31}$ In his sudden recognition of Marina's high status Lysimachus is rather like Frederick in Aphra Behn's Restoration play The Rover (1677), who complains that he does not want "to be trussed up for a rape upon a maid of quality, when we only believe 
we ruffle a harlot" ${ }^{32}$ Lysimachus's newly discovered self-disgust can be very funny in performance, and the scene echoes the little exchange between the two gentlemen previously converted by Marina, in which one declares "I am for no more bawdy houses," asking "Shall's go hear the vestals sing?" and his companion replies "I'll do anything now that is virtuous, but I am out of the road of rutting for ever" (4.5.6-9). The suddenness of conversion is perhaps part of the point: it is not the product of reasoned argument, but of an overwhelming urge to reject one's former behaviour.

Interpretations along these lines have not, however, convinced some editors and directors; if Pericles is to convince as a late play something has to be done about the brothel scenes. Many scholars have refused to admit them as Shakespeare's work. Fleay is typical of many nineteenth-century commentators when he argues that Shakespeare

would not have indulged in the morbid anatomy of such loathsome characters; he would have covered the ulcerous sores with a film of humour, if it were a necessary part of his moral surgery to treat them at all - and, above all, he would not have married Marina to a man whose acquaintance she had first made in a public brothel, to which his motives of resort were not recommendatory, however involuntary her sojourn there may have been. ${ }^{33}$

Marina, Fleay's eight-scene version of Pericles, excises the brothel scenes altogether, and it is not surprising that Dowden gratefully accepted Fleay's assessment of the authorship of the play given that the scenes are difficult to reconcile with his model of the late play as " mellowed, refined, made exquisite". Later scholars have been less squeamish, and more willing to countenance the idea that Shakespeare might have "indulged in [...] morbid anatomy", but they have often continued to harbour doubts about the scenes' authorship and textual integrity. With the re-dating of Pericles to 1608, supposed deficiencies in the writing of these scenes could no longer be attributed to the playwright's youth and inexperience, but the discovery of Wilkins's Painful Adventures and the general acceptance among scholars that the play is a collaboration have offered alternative solutions. These include "Wilkins's involvement, at some stage of the play's development, in the writing of portions of these largely Shakespearian scenes" and the suggestion that the Painful Adventures may provide material belonging to an original version of the play as it was staged by the King's Men. ${ }^{34}$

Although these developments have rarely been linked, it is unsurprising that the brothel scenes have been subjected to substantial revision in both theatrical productions and editions of Pericles. The idea of the Shakespearean "late play" took a decisive hold on Pericles at precisely the point at which the play began to make an impact on the stage: C.L. Barber's influential essay “'Thou that Beget'st Him that Did Thee Beget': Transformation in Pericles and The Winter's Tale" was published in 1969, the same year as the play was staged at Stratford-on-Avon by Terry Hands in a version that drew on Painful Adventures at crucial moments. ${ }^{35}$ Barber's essay stresses reconciliation, renewal and visionary revelation, and Hands described Pericles to his cast in strikingly similar terms: "[t]he play's subject is love. Its mechanism is birth and resurrection, its techniques revelation and miracle". ${ }^{36}$ With their frank treatment of sexual and economic exchange, their assertive and inscrutable Marina, and their evasive and ambiguous Lysimachus, the brothel scenes run contrary to these readings of the play. In a not untypical response, Roger Warren describes "Lysimachus' behaviour and personality" as "a principal (perhaps the principal) puzzle of the play." He suggests that the governor's responses to Marina in the quarto can only be made "theatrically convincing by ingenious playing", and remarks that Marina's two brief speeches in the quarto "hardly seem enough to 
arouse such amazement and admiration in the sexual predator that we have seen in the early part of the scene." ${ }^{37}$ Critics such as Warren thus see in the quarto text of Pericles one of the features identified by Ulrici in early Shakespeare: its characters appear "now and then still without solidity, wavering, and uncertain", and they make it unfit for the status of a late Shakespearean work.

Paradoxically, therefore, editors and directors have looked outside the Shakespearean text to solve the puzzle of Pericles's uneasy status as Shakespearean late work, incorporating material from the Painful Adventures into the brothel scenes in order to smooth out their problems of tone and characterisation. Wilkins's version of the events of Act 4 , Scene 5 lacks many of the disjunctions of the quarto: Marina makes a far more extended and emotive appeal, more is said about the physical interactions between the characters, and Lysimachus's responses are significantly different. The exchange comes to a climax as Marina says:

O my good Lord, kill me, but not deflower me, punish me how you please, so you spare my chastitie, and since it is all the dowry that both the Gods haue giuen, and men haue left to me, do not you take it from me; make me your seruant, I will willingly obey you; make mée your bond woman, I will accompt it fréedome; let me be the worst that is called vile, so I may still liue honest, I am content: or if you thinke it is too blessed a happinesse to haue me so, let me euen now, now in this minute die, and Ile accompt my death more happy than my birth. With which wordes (being spoken vpon her knées) while her eyes were the glasses that carried the water of her mis-hap, the good Gentlewoman being mooued, hee lift her vp with his hands, and euen then imbraced her in his hart, saying aside Now surely this is Uirtues image, or rather, Uertues selfe, sent downe from heauen, a while to raigne on earth, to teach vs what we should be. So in steede of willing her to drie her eyes, he wiped the wet himselfe off, and could haue found in his heart, with modest thoughts to haue kissed her, but that hée feared the offer would offend her..$^{38}$

In addition to its apparently more satisfactory narrative and characterisation, this version includes some elements that seem to relate to stage presentation, such as the submerged iambic pentameter of much of the dialogue, the speech described as an "aside", and physical movements that might be reproduced on stage: she kneels and weeps; he lifts her up, and wipes her eyes. Its appeal to a director wishing to supplement Marina's part and regularise her interaction with Lysimachus is clear.

Directors preceded editors in drawing on Painful Adventures. Douglas Seale's 1954 Birmingham Repertory Theatre appears to have been the first, its adaptations including Lysimachus's admission "that he had come to the brothel 'with ill intent", ${ }^{39}$ but the most influential production to make use of Wilkins was Terry Hands's 1969 Royal Shakespeare Company revival. The programme comments explicitly on the textual adaptation: "[t]he present version leans more heavily on the First Quarto than is usual, and where the text is excessively corrupt or actually missing, includes some blank verse passages from Wilkins's The Painfull Adventures of Pericles Prince of Tyre" ${ }^{40}$ Its version of Act 4, Scene 5 draws heavily on Painful Adventures, and the surviving promptbook indicates both the additions from Wilkins and the later deletions that were made as the director and cast strove to make the adaptation ready for the stage. I have introduced bold text here and throughout this section to indicate what has been taken or adapted from Wilkins. Hands's text reads:

LYS: How's this? how's this? be sage.

MAR: What reasons in

Your justice which has power o'er all

To undo one. If now you take from me 
Mine honour, you are like to him that makes

A gap into forbidden ground - whereto

With licensed hand the many come to prove

The evil of your own base industry.

Why stain your justice and abuse your name

But to impoverish me?

LYS: Why yet this house

Wherein thyou livest is but a sty, a sink

of all men's sins, a nurse of wickedness;

How canst thou then be otherwise than nought

That dealeth here dear physic of disease?

MAR: How canst thou then be otherwise than nought

That knowst there's such a house, yet comest within't?

Is there a need, my yet good lord, if I

Set fire before me, that I straight must fly

And burn myself?

o my good lord, yet spare my innocence;

'Tis all the dowry that the gods have given;

'Tis all remains of her by all forsa'en;

Make me your servant, I will joy t'obey you,

Make me your bondmaid, I'll account it freedom;

If I may be the worst that's called vile,

So I may live in honour, I'm content

Or if you think it too much happiness

To have me stay so, prithee let me now

Now in this minute die, and I'll account

My death more happy than my birth.

O that the gods

Would set me free from this unhallowed place,

Though they did change me to the meanest bird

That flies in the purer air!

LYS: I did not think

Thou couldst have spoke so well, ne'er dreamt thou couldst.

Had I brought hither a corrupted mind,

Thy speech had altered it. ${ }^{41}$

Hands retains the line "Had I brought hither a corrupted mind", but even once the lines marked for deletion are excluded he more than doubles the length of Marina's appeal to Lysimachus; in the process, he removes her frank criticism of the "Stie" in which "diseases haue beene solde deerer then phisicke", but he relocates the word "sty" into one of Lysimachus's speeches. In addition, he adapts some of Wilkins's directions for movement in the scene. In the promptbook, Marina is directed to kneel as she says "O my good lord," and when Lysimachus speaks for the second time a direction indicates the required movement: "M. prostrate. L. kneels beside her". Yet Hands's adaptation does not entirely jettison the quarto's sardonic edge. When Lysimachus entered he shiftily placed a hat on the statue of Priapus that featured prominently in the staging, and a note in the promptbook on the lines "If thou dost / Hear from me it shall be for thy good" (4.5.120-121) reads "Takes hat off priapus, looks at it, replaces hat. (RUDE!)". Reviewing the production in The Spectator, Hilary Spurling noted that "Marina, for all her stainless, miracle-working chastity, has a rough tongue and a shrewd knowledge of the world". ${ }^{42}$ The production thus attempted to correct the incomplete or problematic characterisation often associated with early modern writing, but resisted moving too far into the "romantic" mode of the late play in these scenes. 
Nearly twenty years later, editorial practice caught up with the stage, and these two venues for adaptation began to work together to produce a Pericles that was more of a late play than it had been hitherto. ${ }^{43}$ In his 1976 New Penguin edition, Philip Edwards drew on Painful Adventures to make sense of some difficult and probably corrupt passages in the quarto, though, interestingly, he did not amend Act 4, Scene 5 in this manner. ${ }^{44}$ The Oxford Shakespeare: The Complete Works, published in 1986, went much further, presenting what was billed as a "A Reconstructed Text". ${ }^{45}$ With the assistance of MacDonald P. Jackson, Gary Taylor edited the play according to the hypothesis that The Painful Adventures is likely to have reported parts of the play as performed "both more accurately and more fully than the quarto" and his edition drew freely on both texts. ${ }^{46}$ These changes affect in particular the exchange between Lysimachus and Marina:

MARINA. Let not authority, which teaches you

To govern others, be the means to make you

Misgovern much yourself.

If you were born to honour, show it now;

If put upon you, make the judgement good

That thought you worthy of it. What reason's in

Your justice, who hath power over all,

To undo any? If you take from me

Mine honour, you're like him that makes a gap

Into forbidden ground, whom after

Too many enter, and of all their evils

Yourself are guilty. My life is yet unspotted;

My chastity unstainèd ev'n in thought.

Then if your violence deface this building,

The workmanship of heav'n, you do kill your honour,

Abuse your justice, and impoverish me.

My yet good lord, if there be fire before me,

Must I straight fly and burn myself? Suppose this house -

Which too too many feel such houses are -

Should be the doctor's patrimony, and

The surgeon's feeding; follows it, that I

Must needs infect myself to give them maint'nance?

LYSIMACHUS. How's this? How's this? Some more, be sage.

MARINA. [kneeling] For me

That am a maid, though most ungentle fortune

Have franked me in this sty, where since I came

Diseases have been sold dearer than physic -

That the gods would set me free from this unhallowed place,

Though they did change me to the meanest bird

That flies i'th' purer air!

LYSIMACHUS. [moved] I did not think

Thou couldst have spoke so well, ne'er dreamt thou couldst.

[He lifts her up with his hands]

Though I brought hither a corrupted mind,

Thy speech had altered it,

[He wipes the wet from her eyes]

and my foul thoughts

Thy tears so well hath laved that they're now white.

I came here meaning but to pay the price,

A piece of gold for thy virginity;

Here's twenty to relieve thine honesty.

Persever still in that clear way thou goest,

And the gods strengthen thee. 
(19.86-135)

Like Hands in his 1969 production, Taylor increases Marina's spoken role in the scene considerably, and he also uses material from Painful Adventures to rework Lysimachus's lines. Here, the governor freely repents his former corruption, and the additional lines and some cuts and rearrangements in his final speech make him more measured and less shifty than his counterpart in the quarto. Together with the revisions to Marina's role that had already been established on stage, these changes to Lysimachus helped to make the scene as a whole more sentimental, revelatory and "late".

Intriguingly, as Pericles became more like a "late play" and thus a more integral part of the Shakespearean canon, it also seems to have started to shape conceptions of the late play itself. Reviewing Phyllida Lloyd's 1994 production at the National Theatre, and comparing it unfavourably with Thacker's, John Gross commented that the play "has an imaginative coherence, and its governing themes - loss and restoration, innocence surviving in a world of corruption - pervade it just as thoroughly as they do Shakespeare's other late plays". ${ }^{47}$ The theme of "innocence surviving in a world of corruption" clearly derives from Pericles, and it alerts us to the impact that revisions to the brothel scenes were beginning to have on broader understandings of Marina as her rough edges were smoothed off. These shifts were also registered elsewhere. Taylor's edition is praised by Valerie Wayne for presenting "a more articulate Marina" who "becomes an important agent in the play's critique of those in power", but she criticizes the inclusion of stage directions based on Wilkins's narration, asking "[i]s it possible to adopt Marina's resistance in Wilkins without also importing her tears and abjection?" 48 When Marina's conversion of Lysimachus becomes less a miracle and more a piece of emotive rhetoric, she becomes more purely a late play heroine.

These problems have become yet more acute in later productions and editions of Pericles. The text for David Thacker's RSC production, staged at the Swan in 1989, was based on Taylor's edition, but departed from it in this scene in some important ways, softening the presentation of Lysimachus even further and making Marina's appeal more sentimental. In Wilkins's account, Lysimachus sees Marina from his window and pities her, resolving "that since shée must fall, it were farre more fitter, into his owne armes, whose authoritie could stretch to doe her good, than into the hote imbracements of many, to her vtter ruine" (sig. H2r), and when he arrives at the brothel he asks for "that same fresh péece of stuffe, which by their proclamation they tolde, they had now to make sale of" (sig. H2v). Although the Bawd says that he is a "fauourer of our calling" (sig. H2r) there is little to suggest that Lysimachus is a regular customer. Thacker therefore modified the lines, "Wholesome iniquity have you, that a man may deal withal and defy the surgeon?" (4.5.33-34), to read "have you that wholesome iniquity which by your proclamation you have now to make sale of, that a man may deal withal and defy the surgeon". ${ }^{49}$ In this version, after Lysimachus asks Marina to take him to "some private place", she makes an emotional appeal, using some of the lines also adopted by Hands, but omitting all of the political critique of that version and Taylor's:

MARINA My yet good lord, oh spare my innocence,

Tis all the dowry that the gods have given.

LYSIMACHUS How's this, how's this?

MARINA Make me your servant and I will obey;

Make me your slave, I will account it freedom.

Or let me be the worst that's callèd vile,

So I may live in honour, I'm content. 
Or if this be too blessed a happiness,

Let me this minute die

My death will be more happy welcome than my birth.

Here, only Lysimachus's “How's this, how's this?" remains from the quarto. According to Roger Warren, who attended rehearsals, the new speech was devised because Suzan Sylvester, playing Marina, wanted her to make a different kind of appeal from that provided in the Oxford edition. "Instead of boldly taking on Lysimachus and accusing him of abusing his authority", he comments, "Marina now made a purely personal appeal"; this "made Marina a much simpler character, less eloquent, less miracle-working, in short less distinguished". ${ }^{50}$ As this background suggests, uses of Wilkins by editors, directors and actors are conditioned by their own interpretations of the scene, and by the assumptions that they bring to it.

Although Warren was clearly made uneasy by the effects of Thacker's adaptation of Act 4, Scene 5 - preferring Richard Ouzounian's 1986 production at Stratford, Ontario, in which Kim Horsman's Marina had to work hard to convert Joseph Ziegler's physically violent Lysimachus ${ }^{51}$ - his own single-volume edition for the Oxford Shakespeare, published in 2003, draws on some of the same material. Although he retains her attack on Lysimachus's abuse of his office, Warren removes her attack on the brothel as a "sty", and substitutes an extended version of the lines used by Thacker:

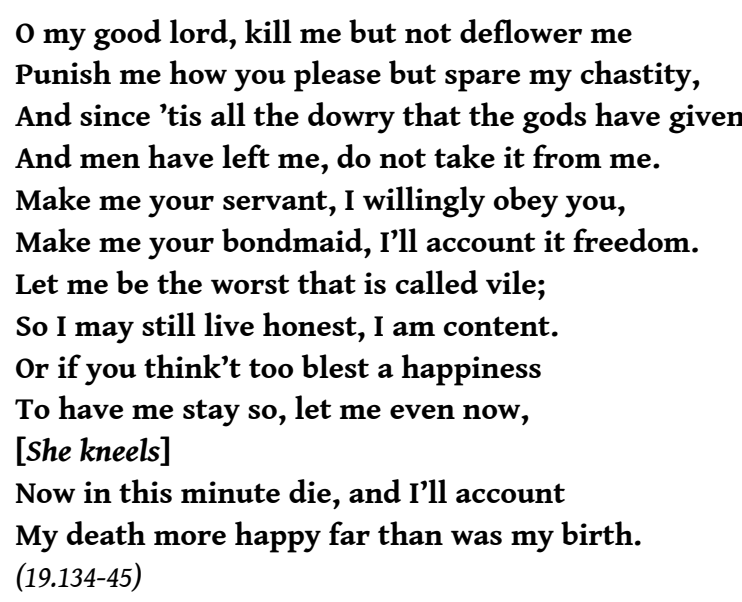

As his notes and introduction stress, Warren's changes aim to make Marina's appeal to Lysimachus yet more "personal" and "passionate", ${ }^{52}$ and he also tries to make Lysimachus's behaviour more straightforward, adding lines to his response to her plea:

LYSIMACHUS. [lifting her up] Now surely this is virtue's image, nay,

Virtue herself sent down from heaven a while

To reign on earth and teach us what we should be! -

I did not think thou couldst have spoke so well,

Ne'er dreamt thou couldst.

I hither came with thoughts intemperate,

Foul and deformed, the which thy pains

So well have laved that they are now white.

I came here meaning but to pay the price,

A piece of gold for thy virginity;

Here's twenty to relieve thine honesty.

Persever still in that clear way thou goest,

And the gods strengthen thee.

(19.146-58) 
versions of the exchange between Marina and Lysimachus have less of the awkwardness and embarrassment of the quarto's dialogue, especially for Lysimachus. The scene also becomes more straightforwardly emotional and credible; Lysimachus's additional lines underline the wondrous impact of Marina's words, but the general expansion of the scene also makes that impact less mysterious. Tonally, the scene also becomes more of a piece with the later encounters between Marina and Pericles, and Thaisa and Pericles. For Warren, the emotional appeals made by his version of Marina "come from Wilkins's account of the scene, but they are absolutely characteristic of Shakespeare's juxtaposition of such extreme contrasts in his late plays". ${ }^{33}$ What is elided here is the critical work that has gone into the creation of the "late play" itself.

Editorial and theatrical reworkings of Pericles thus bring the play closer to the model of the Shakespearean late play offered by Dowden and later scholars: tonally consistent, wondrous, reconciliatory and sentimental, avoiding what Dowden calls "the extremes of broad humour and tragic intensity". They write out some of the "wildness and irregularity" of both the narrative and its characters, and move the brothel scene away from the quarto's more unsettling version, with its shifty Lysimachus and assertive Marina. Where Fleay excised the brothel scenes as incompatible with his Marina, editors and directors have civilised even those elements that he thought irreconcilable with Shakespearean authorship.

31 Yet problems remain. Incorporating material from The Painful Adventures gives Marina more to say in each of these adaptations. However, her greater articulacy is not uncomplicated, nor is the greater attention that is consequently thrown onto the play's youngest character; one does not have to be as hostile to conflation as Anthony Hammond and Doreen DelVecchio, who describe such productions as "Wilkinsised", ${ }^{4}$ to be uneasy with some of its effects. As Lori Humphrey Newcomb comments, "[t]o bring material from Wilkins's novella into the play cannot merely be a pragmatic solution to an intertextual puzzle if it celebrates gendered violence in either the artists' or the editors' choices". ${ }^{55}$ Adaptations risk making Marina more abject - especially when they include her plea that the governor enslave or kill her rather than taking her chastity, or draw on the implied stage directions in Painful Adventures - even as they make her and the play in which she appears more emotionally coherent and less "rough-tongued".

As we have seen, the re-dating of Pericles and the emergence of the idea of the "late play" have had far-reaching consequences for the play on both stage and page. In a somewhat paradoxical process, acknowledgement that the play is a collaboration and editorial processes that have aimed to restore something of the original version of Act 4 as it was staged by the King's Men have produced a unified effect. That is, the fact that the play is only partially Shakespearean has enabled it to become gradually more "Shakespearean" in terms of both its text and its place within the canon. Happy as they were to amend Shakespeare's text, it would not have occurred to late eighteenth-century editors that Pericles should be more like a late play, partly because that model had not yet fully emerged, partly because they were convinced that it was early, and partly because some of them did not believe that it was even partly Shakespearean. Yet by paying attention to the old tradition that Pericles was written by a young Shakespeare at the outset of his career, we can see some of the manoeuvres that are required to make it fully "late." 


\section{NOTES}

1. I am very grateful to the Société Française Shakespeare for inviting me to speak at their 2015 conference, and to Laetitia Sansonetti and two anonymous readers for their feedback and guidance. I would also like to thank Gordon McMullan and students on the King's College London module "Late Shakespeare" for discussions about Pericles.

2. John Dryden, The Poems of John Dryden: Volume One: 1649-1681, ed. Paul Hammond, 1995, repr. Abingdon, Routledge, 2014, p. 339 (1. 16-19).

3. Act, scene and line numbers in this essay follow Pericles, ed. Suzanne Gossett, Arden Shakespeare Third Series, London, Thomson Learning, 2004, from which all quotations are taken unless indicated otherwise.

4. William Shakespeare, The Works of Mr. William Shakespear; In Six Volumes, ed. Nicholas Rowe, London, 1709, 1: vii.

5. Ibid.

6. Ibid., 1: vi-vii.

7. For recent studies of the chronologies and their versions of Shakespeare's career, see Gordon McMullan, Shakespeare and the Idea of Late Writing: Authorship in the Proximity of Death, Cambridge, Cambridge University Press, 2007, p. 128-159; Peter Kirwan, Shakespeare and the Idea of Apocrypha: Negotiating the Boundaries of the Dramatic Canon, Cambridge, Cambridge University Press, 2015, p. 36-47.

8. Edmond Malone, "Attempt to Ascertain the Order in Which the Plays Attributed to William Shakespeare Were Written", in William Shakespeare, The Plays of William Shakespeare in Ten Volumes [...] To Which Are Added Notes by Samuel Johnson and George Steevens, ed. Edmond Malone, second edition, 10 volumes, London, 1778, 1: 269-346, p. 274.

9. Ibid., p. 284; idem, Supplement to the Edition of Shakspeare's Plays Published in 1778 by Samuel Johnson and George Steevens, 2 volumes, London, C. Bathurst et al., 1780, 2: 186.

10. See Malone, “Attempt", p. 274-275.

11. Edward Capell, Notes and Various Readings to Shakespeare, 3 volumes, London, printed 1779-1780 and published 1783, Vol. 2, Part 4, p. 185. The title-page of each volume of Capell's edition of Mr William Shakespeare his Comedies, Histories, and Tragedies, 10 volumes, London: Dryden Leach for J. and R. Tonson, 1767-8, advertises the Notes as forthcoming: "Whereunto will be added, in some other Volumes, NOTES, critical and explanatory, and a Body of VARIOUS READINGS entire". Capell's views on the late plays were idiosyncratic for his time but now appear in some respects far-sighted: he places as the final plays Othello (1611), Cymbeline (1612), Henry VIII (1613), The Winter's Tale (1613) and The Tempest (1614).

12. Samuel Taylor Coleridge, The Literary Remains of Samuel Taylor Coleridge, ed. Henry Nelson Coleridge, 4 volumes, London, William Pickering, 1836-1839, 2: 86-87. For slightly different versions of these lists, see Coleridge's Shakespeare Criticism, ed. Thomas Middleton Raysor, 2 volumes, Cambridge, MA, Harvard University Press, 1930, 1: 237-242.

13. Coleridge, op. cit. 2: 89-90.

14. John Payne Collier, Farther Particulars Regarding Shakespeare, London, Thomas Rodd, 1839, p. 31, 33. On Collier and the Painful Adventures see Arthur Freeman and Janet Ing Freeman, John Payne Collier: Scholarship and Forgery in the Nineteenth Century, New Haven, Yale University Press, 2004, p. 312-313.

15. The most vocal recent proponent of this theory was Eric Sams. See "The Painful Misadventures of Pericles Acts I and II", Notes and Queries, n.s. 38, 1991, 67-90; The Real Shakespeare: 
Retrieving the Early Years, 1564-1594, New Haven, Yale University Press, 1995, p. 171-172, 187-190. For commentary see also MacDonald P. Jackson, Defining Shakespeare: Pericles as Test Case, Oxford, Oxford University Press, 2003, p. 32-37.

16. Dulwich College MSS 1, Article 30, Henslowe-Alleyn Digitisation Project, http://www.henslowealleyn.org.uk/images/MSS-1/Article-030/01r.html (accessed 15 March 2015); S.P. Cerasano, “An Inventory of Theatrical Apparel (c. 1601/2)", http://www.henslowe-alleyn.org.uk/essays/ costumelist.html (accessed 15 March 2015). See also Collier's Memoirs of Edward Alleyn, Founder of Dulwich College: Including Some New Particulars Respecting Shakespeare, Ben Jonson, Massinger, Marston, Dekker, \&c., London, Shakespeare Society, 1841, p. 21-22; Freeman and Freeman, op. cit., p. 346-347.

17. Hermann Ulrici, Shakespeare's Dramatic Art: History and Character of Shakspeare's Plays, trans. L. Dora Schmitz, 2 volumes, London, George Bell and Sons, 1876, 1: 222n, 222-223. The German third edition on which this is based appeared in 1869.

18. Pericles, in The Illustrated Shakespeare: Shakespeare's Plays, with his Life, 3 volumes, New York, Harper and Brothers, 1847, 3: 7 (each play has separate pagination).

19. McMullan, op. cit., p. 22, describes him as "the first critic fully to delineate a Shakespearean late style and the starting point for all work on the subject".

20. Edward Dowden, Shakspere: A Critical Study of his Mind and Art, London, Henry S. King, 1875, p. ix.

21. F.G. Fleay, "On the Play of Pericles", Transactions of the New Shakspere Society, Series 1, Part 1, 1874, 195-209.

22. Ibid., p. 211-241.

23. Dowden, op. cit., p. 403.

24. Idem, Shakspere, Literature Primers, London, Macmillan, 1877, p. 56-57.

25. Ibid., p. 55, 144-146.

26. Op. cit., p. 45.

27. For a history of these developments, and a convincing case for the play as a collaboration between Shakespeare and Wilkins, see Jackson, op. cit.

28. G.E. Bentley's thesis in "Shakespeare and the Blackfriars Theatre", Shakespeare Survey 1, 1948, 38-50, that from 1609 Shakespeare wrote "with the Blackfriars in mind and not the Globe" (p. 46), has been much debated. See McMullan, op. cit., p. 96-99. Andrew Gurr argues that only The Tempest shows definite signs of Blackfriars composition: see “The Tempest's Tempest at Blackfriars", Shakespeare Survey 41, 1989, 91-102.

29. There was only one nineteenth-century production, that of Samuel Phelps in 1854. For detailed accounts of the play's performance history see Michael Mullin, "Pericles", in Shakespeare Around the Globe: A Guide to Notable Postwar Revivals, ed. Samuel L. Leiter, New York and London, Greenwood Press, 1986, p. 555-567; Roger Warren, Staging Shakespeare's Late Plays, Oxford, Clarendon Press, 1990, p. 208-237; Anthony Hammond and Doreen DelVecchio, ed., Pericles, Prince of Tyre New Cambridge Shakespeare, Cambridge, Cambridge University Press, 1998, p. 15-26; David Skeele, Thwarting the Wayward Seas: A Critical and Theatrical History of Shakespeare's Pericles in the Nineteenth and Twentieth Centuries, Newark, NJ, University of Delaware Press, 1998; Skeele, ed., Pericles: Critical Essays, New York, Routledge, 2000, Part III; Gossett, Pericles, p. 2-8, 86-106.

30. William Shakespeare, The Late, and Much Admired Play, called Pericles, Prince of Tyre, London, 1609, sigs. G4v-H1r. STC 22334.

31. Gossett, op. cit., p. 356; see also Pericles, ed. Hammond and DelVecchio, p. 170.

32. Aphra Behn, The Rover and Other Plays, ed. Jane Spencer, Oxford, Oxford University Press, 1995, 4.5.122-123. Although the plays have little in common otherwise, they suggest some continuities in the ways in which social class and sexual exploitation might be related.

33. Fleay, op. cit., 196.

34. See Jackson, op. cit., p. 230-232 (quotation from p. 232). 
35. C.L. Barber, “'Thou that Beget'st Him that Did Thee Beget': Transformation in Pericles and The Winter's Tale", Shakespeare Survey 22, 1969, 59-67.

36. Note "From the director's first talk to the cast" in the programme for Pericles (1969).

37. Warren, op. cit., p. 225; idem, ed., Pericles, Oxford Shakespeare, Oxford, Oxford University Press, 2003, p. 49.

38. The Painful Adventures of Pericles, Prince of Tyre, London, 1608, sig. H3 ${ }^{\mathrm{v}}$. STC 25638.5.

39. J.C. Maxwell, ed., Pericles, Cambridge Shakespeare, $2^{\text {nd }}$ edition, Cambridge, Cambridge University Press, 1969, p. xxxix.

40. RSC programme for Pericles (1969).

41. Shakespeare Birthplace Trust, RSC/SM/1/1969/PER2.

42. Hilary Spurling, "Stranger Things at Stratford", Spectator, 11 April 1969, p. 481.

43. For helpful summaries of editorial approaches, see Jackson, op. cit., p. 218-221; Suzanne Gossett, “'To Foster is not Always to Preserve': Feminist Inflections in Editing Pericles', in In Arden: Editing Shakespeare, ed. Ann Thompson and Gordon McMullan, London, Thomson Learning, 2003, p. 65-80.

44. See Philip Edwards, ed., Pericles, New Penguin Shakespeare, Harmondsworth, Penguin, 1976, p. 204.

45. Stanley Wells, Gary Taylor, John Jowett and William Montgomery, ed., The Oxford Shakespeare: The Complete Works, Oxford, Clarendon Press, 1986, p. 1037.

46. Ibid. For background on the edition see Jackson, op. cit., 218-20.

47. John Gross, review of Pericles, Daily Telegraph, quoted in Melissa Gibson, "Pericles at the Royal National Theatre [1994]", in Skeele, Pericles, p. 332-338 (p. 336).

48. "Political and Textual Corruption in Pericles", unpublished paper for Pericles seminar, Shakespeare Association of America, 1999, quoted in Gossett, ed., Pericles, p. 53-54. See also Gossett, op. cit.; Lori Humphrey Newcomb, "The Sources of Romance, the Generation of Story, and the Patterns of the Pericles Tales", in Staging Early Modern Romance: Prose Fiction, Dramatic Romance, and Shakespeare, ed. Mary Ellen Lamb and Valerie Wayne, Abingdon, Routledge, 2009, p. 21-47.

49. Shakespeare Birthplace Trust, RSC/SM/1/1989/PER1. For a detailed account of the adaptation of this scene see Warren, Staging, p. 226-228.

50. Warren, Staging, p. 227.

51. Ibid., p. 223-228.

52. Idem, Pericles, p. 51.

53. Ibid., p. 52.

54. Hammond and DelVecchio, op. cit., p. 20.

55. Newcomb, op. cit., p. 36.

\section{ABSTRACTS}

Once viewed as the first play composed by a young Shakespeare, since the late nineteenth century Pericles has instead been viewed as the first of the 'late' plays. This essay explores the processes through which this occurred, and their implications for our understanding of recent editorial and theatrical interventions. By paying attention to the old tradition that Pericles is an early work, we can perceive some of the manoeuvres that are required to make it fully 'late'. 
Autrefois considérée comme la première pièce composée par un jeune Shakespeare, depuis la fin du XIX ${ }^{\mathrm{e}}$ siècle Périclès est plutôt perçue comme la première des "pièces tardives ». Cet article explore les mécanismes de cette évolution et leurs implications pour notre compréhension de pratiques éditoriales et théâtrales récentes. En prêtant attention à la vieille tradition selon laquelle Périclès est une œuvre de jeunesse, nous pouvons nous faire une idée des opérations nécessaires afin d'assurer sa place parmi les pièces « tardives ».

INDEX

Mots-clés: adaptation, canon, carrière, édition du texte, pièces tardives, Shakespeare William, Wilkins George

Keywords: career, late plays, textual editing

\section{AUTHOR}

LUCY MUNRO

King's College London 